\title{
Methodological problems of modern pedagogy
}

\author{
Hryhoriy Vasianovych ${ }^{1}$, Radosław Muszkieta ${ }^{2}$
}

\author{
${ }^{1}$ Department of Humanities and Social Work of Lviv State University of Life Safety, Lviv, Ukraina \\ ${ }^{2}$ Faculty of Earth Sciences, Nicolaus Copernicus University, Torun, Poland
}

Keywords: physical methodology, teacher, pedagogical reality, pedagogical activity, science, content of pedagogical education, methodological culture of a teacher.

Ключові слові: методологія, педагог, педагогічна дійсність, педагогічна діяльність, наука, зміст педагогічної освіти, методологічна культура

\begin{abstract}
The article analyzes the nature and the content of the term "methodology", and concludes that so far tere is no clear approach to the notion definition. Much attention is paid to determine the relationship between methodology and science, and to reveal dialectical aspects of this relationship.The author studies the main factors of methodology influence on improving teaching reality and pedagogical activity, and defines the role of methodology in forming the content of pedagogical education. It is proved that the improvement of the educational process and study of its main components depends on methodological culture of a teacher.
\end{abstract}

\begin{abstract}
Анотація
У статті аналізується сутність і зміст поняття «методологія», на основі чого робиться висновок про те, що до цього часу не існує однозначного підходу у визначенні цієї дефініції. Значна увага приділяється питанням з'ясування взаємозв'язку методології і науки, розкриваються діалектичні аспекти цього взаємозв'язку. Досліджуються провідні чинники впливу методології на удосконалення педагогічної дійсності і педагогічної діяльності. Визначається роль методології у формуванні змісту педагогічної освіти. Доводиться, що удосконалення навчально-виховного процесу, дослідження його основних складових безпосередньо залежить від методологічної культури педагога.
\end{abstract}

\section{Introduction}

Modern pedagogy is going through hard times. This has resulted not only from the crisis in Ukraine and its educational system accordingly, but also from purely internal problems of development. From the standpoint of evidence and logic of events development, each science has its own laws of sustainability and progress, has its lifelong general and specific principles, rules, object of study, categorical apparatus and so on. This fully concerns such a dynamic science as pedagogy, because knowledge of the nature, effect 
of educational laws and regularities helps teacher to find the correct answers to the key questions of educational reality and practice. Academician Ivan Zyazyun insistently proved that traditional pedagogy is objectively unable to meet the growing imperatives of our time [9, c. 20-37]. Thus, todays urgent issue is to overview many established pedagogical approaches primarily concerning the conceptualization of the content of modern education, understanding the nature and the content of educational activity, educational process, determining the place, role and real possibilities of modern educational technology application, determining conditions, principles, forms, methods and means of formation methodological culture of a teacher, etc. Besides, it is necessary to be well aware that pedagogy as a science, though having its own status of functioning but being in a range of other sciences, is certainly under their influence (philosophy, psychology, cultural studies, sociology, logic, etc.). In our opinion, pedagogic methodology can help to solve these and other complex issues of modern pedagogy.

\section{The object of the article}

The object of the article is to analyze the methodological problems of modern pedagogy and to reveal the possibilities of its impact in solving urgent educational issues of today.

\section{The subject matter of the paper}

Significant number of domestic and foreign scientists studied the problems of methodology. Ukrainian scientists (I. Bekh, M. Bilukha, S. Honcharenko, I. Zyazyun, V. Kosolapov, S. Mochernyi, V. Rybalka, M. Savchyn, D. Stechenko, S. Farenik, O. Chmyr, N. Chuprina) focused their attention not only on clarifying the nature and content of the definition of "methodology" but also on justifying the role and place of methodology in scientific research, system of functioning of secondary and higher education, its humanization and humanitaryzation. They determined real possibilities of the methodology in personality shaping etc. Foreign scientists (M. Weber, W. Zavyazinskyi, M. Kahan, V. Krayevskyi, L. Mikeshyna, V. Okon', A. Novikov, B. Russell, J. Searle, B. Serikov, Yu. Henninhsen etc.) studied both general and specific issues of scientific knowledge and cognition development, analyzed the problem of interrelation between methodology and creativity, mutual understanding, prognosis of education development, etc.

\section{The essence and content of the notion "methodology"}

The term "methodology" is one of the most uncertain, ambiguous, and even contradictory. The analysis of scientific sources shows that there are different approaches to understanding and determining the definition of "methodology". D. Srechenko and O. Chmyr hold to an opinion, according to which "the methodology is the philosophical study of cognition methods. In a broad sense methodology is a way of understanding the structure of science and methods of its work, in the narrow sense it is a set 
of principles, methods, techniques and research procedures used in a given field of knowledge (specific scientific methodology)" [13, c. 82]. In our opinion we can agree with this definition perhaps in part because the methodology is indeed the science of learning methods. Instead, scholars interpreted more widely modern definition of the term "methodology". In particular, famous methodologist of pedagogical science V. Krayevskyi substantiated his own position, according to which, the methodology has three levels: philosophical knowledge concerns the first of them; general scientific knowledge composes second level; the third level is characterized by specific scientific knowledge. Thus, according to the scientists, it is appropriate to talk about: a) general philosophical; b) general scientific and c) specific scientific methodology. V. Krayevskyi noticed that some scientists distinguish fourth level of methodology that is formed by technique and technology of research. $\mathrm{He}$ stuck to the definition formulated by M. Danilov "Pedagogical methodology is a system of knowledge concerning the foundations and structure of pedagogical theory, the principles of the approach and method of obtaining knowledge that reflects pedagogical reality" and further he stressed that it should be added the following: " ... as well as the system of activity concerning obtaining knowledge and grounding of programs, logic and methods, assessing the quality of specially-scientific pedagogical researches" [10, c. 17-18].

Academician S. Honcharenko noted that the term "methodology" is widely regarded as something abstract, distant from life. However this is far from being the case. This is the methodology that defines the strategies, forms and methods of scientific research. The scientist also followed the "leveled" approach concerning determination of the outlined concept. At the same time he emphasized the functional significance of the methodology and has formulated the following generalized definition: "Methodology is a system of knowledge about the structure of pedagogical theory, the principles of the approach and methods of acquiring knowledge that reflects the educational reality; it is the system of activity aimed at obtaining such knowledge and grounding of programs, logic and methods, assessing the quality of speciallyscientific pedagogical researches" [4, c. 499].

S. Honcharenko stressed that in this definition, along with a system of knowledge concerning the structure of pedagogical theory, principles and methods of acquiring knowledge the system of researcher's activity aimed at knowledge obtaining is singled out. Thus, the subject of methodology serves as the correlation between the pedagogical reality and its reflection in pedagogical science. The written above shows that approaches of V. Krayevskyi and S. Honcharenko are almost identical.

Defining the notion of "methodology" Polish scientists V. Okon' followed the position according to which it "is the science of methods of scientific reality that covers means of preparation to research, the research itself, and study of its results" $[15$, c. 246]. 


\section{Methodology and pedagogical science}

Today there is a generally established view that pedagogy is the only science dealing with education, therefore, the science of training and upbringing. This does not mean that other sciences do not study certain problems of modern pedagogy. Today pedagogical anthropology, hermeneutics, phenomenology, synergy and so on gained scientific status and are powerfully utilized in scientific knowledge (on the methodology level). Instead, general pedagogy is the only special science dealing with education. This is due to the fact that only pedagogy as a science studies problems of education in its entirety. For pedagogy education is the only proper object of study. S. Honcharenko states that "the object of pedagogy is special, socially and personally determined activity, characterized by pedagogical goal setting and pedagogical leadership in social inclusion of a human" [5, c. 645]. The scientist noticed that it is used to believe the subject of pedagogy to be upbringing. But today it is more appropriate and "... correct to consider the subject of pedagogy to be the study of the essence of human personality formation and development and on this basis processing the theory and methodology of education as a specially organized pedagogical process" $[5, c$. 645].

S. Honcharenko explained that this definition directs researchers and teachers practitioners to learning and comprehensive understanding of the process of individuality development and profound dependencies that exist between this development and education.

It should be emphasized that although the process of obtaining pedagogical knowledge is a subject of the general laws of scientific knowledge, pedagogical science has its own specifics. It is due to the fact that it combines two major functions: scientific theoretical and constructive technical (normative, regulatory) that are usually divided among different disciplines in other scientific fields. In pedagogy these functions are dialectically combined. There are even more essential features of pedagogy, caused by its affiliation with the field of social and humanitarian knowledge, which requires more detailed description. Here we note that the main problem of pedagogical methodology is connection between science and practice. This primarily concerns knowledge of educational reality and educational activity, as well as the content of pedagogy, education, and in particular pedagogical education.

\section{The methodology and pedagogical reality}

Any study begins with an analysis of the matter, and in the outlined context pedagogical reality is the matter. Nowadays it is not only colorful, diverse, and highly controversial: it is progressive and regressive, humane and inhumane, perfect and imperfect, traditional and innovative, etc. G. Hegel considered reality to be realm of spirit and noted that "... in true existence this spirit resembles multicolored carpet, where numerous interests and objectives overlap and compete with one another" [3, c. 382]. 
Today, our reality turned to that way that became apparent contradictions between: the urgent need of legal support to pedagogical education system and its real discrepancy; pedagogical ideals and reality; formal freedom and real lack of freedom of educational process subjects; needs of society in the qualitative training of teaching staff and insufficient level of training; proper status of a teacher in the society and its considerable disparity in view of the social role of a teacher; between traditional and innovative forms, teaching methods, and so on.

Among the totality of these contradictions scholar-methodologist should recognize and distinguish the main ones; their solution will contribute to the improvement of this reality, make it possible to simulate such a system that allows future educational reality to obtain true progressive, humanistic shapes and make the lives of all the subjects of the educational process worthy and happy.

Taking into consideration limits of the article it is better to illustrate the foregoing at least using the example of the contradiction between pedagogical ideals and reality. Retrospective analysis of pedagogical theories and teaching practice clearly shows that the best teachers from different societies and centuries always tended to high educational ideals. The main their goal was to prepare highly educated, fully developed person with humanistic worldview that will be able to understand the necessity of hard work for the benefit of society and feel respect for others. Experience shows that it was impossible to realize these ideals in authoritarian societies. Somewhere they were implemented only partially. This aspect of the problem drew attention of the outstanding Ukrainian teacher H. Vashchenko. He substantiated the nature and the content of Christian educational ideal and opposed it to communistic ideal $[2,191 \mathrm{c}$. $]$.

L. Yershova made profound scientific research "Transformation of educational ideal in Ukraine ..." [8]. There she has identified the main principles of the educational ideal development (humanism, democracy, national character, and patriotism), singled out the characteristic features of the main paradigms of educational ideal; found the key merits of educational ideal, etc. Describing the current state of the formation of educational ideal, L. Yershova proves that if in1994 - 2004 years a conflict of ideals began to emerge in Ukraine, then from 2005 real confrontation of the ideals set up in all the areas of the society. Unfortunately, it still exists today. In our opinion, the biggest negative of this state, is that people stay remote from reality, they are locked in their inner world, everything except their own virtual space becomes unfamiliar. There comes a dream of reason and conscience, and as you know dream of reason produces monsters...

The reality, where moral standards and principles are essentially deformed, where law is disregarded, while corruption and the power of the "golden calf" prosper can destroy the most advanced educational and social ideals at all. This condition was characterized by G. Hegel at his time, who said that the reality replaced ideals. The philosopher wrote: "Everyone creates his own ideal, but eventually one gets something quite different, not similar 
to his ideal; his ideal is replaced by reality, and he forgets about it" [3, c. 426].

Yet, even under these conditions we cannot abandon the humanistic pedagogical ideals. Pedagogical methodology is aimed to lead us to the right path in life, to make the reality be decent of a human. This means that pedagogical methodology, using modern methods of scientific knowledge, should help scientists-teachers to learn both internal and external factors of reality improving; to determine what should and what should not be done to prevent pedagogical ideals from being "replaced" by reality, therefore, preserve reality from becoming absurd, illusory; to examine to what extent of twisted reality teachers can act responsibly, conscientiously, diligently, and where is the line when they "burn out" and become indifferent not only to their students, but also to themselves; to help analyze and deeply understand what disastrous consequences may occur in the sphere of spirit and morality, if the training and education of future generations is not be based on the humanistic educational ideal.

\section{Methodology and pedagogical activity}

The problem of the nature and content of educational activity was study subject of following domestic and foreign scientists: K. AbulkhanovaSlavska, A. Aleksyuk, S. Amonashvili, O. Anisimov, Yu. Babanskyi, I. Bech, O. Budnik, S. Honcharenko, O. Dubasenyuk, J. Dewey, M. Yevtukh, I. Zyazyun, S. Kachor, T. Levovytskyi, O. Leontyev, T. Nowitski, V. Rybalka, A. Romanovskyi, O. Rudnytska, G. Filipchuk and others.

Pedagogical activity is extremely diverse, even all-inclusive. But in our opinion, it is only worthwhile, when filled with a moral sense, when good is done, when responsibility of an individual is tempered, therefore, the human is created in the course of pedagogical activity. Let's recall how G. Hegel defined the essence of the concept of "education". The philosopher extremely lapidary formulated his opinion: "Pedagogy is the art of making people moral: it considers human as a natural being and shows the way, if following it human can be born again, turning its first nature into another, spiritual one, that can gradually become its habit" [3, c. 205-206]. Then thinker pointed out that everything that origins in the sphere of morality is generated by the activity of spirit, therefore this spirit must be intelligent and amateur. Therefore, only subjectivity is considered to be activity.

Later on this idea was emphasized by prominent psychologist S. Rubinstein. The scientist wrote: "The subject in its acts, in acts of creative initiative is not only manifested and revealed but is also created and defined. Therefore, you can define and create him owing to his deeds..." [12, c. 106].

Academician I. Zyazyun defined pedagogical activity as a meta-activity, as far as it is built over the activity of a pupil/student. Teacher in the course of his/her professional activity does not only define the purpose of education and upbringing but tries to make this goal being perceived, understood and implemented by pupil or student $[11, c .19]$. 
In our opinion, it is necessary to emphasize the fact that the content of pedagogical activity, as well as all every social phenomenon, is constantly changing and is being filled with a new meaning. As scientists prove, the functions of the teacher are also changing. Modern teachers cannot be functionaries anymore, they cannot be limited by knowledge, proficiency, and skills. Teachers' task is to form a coherent personality, and for this they have first of all to be individuals themselves. All this requires from teachers continuous self-improvement, intense mental work, and emotional stress. Today, pedagogical activity can be effective if teachers rather than blindly guide instructions and standards will be able to create new authoring system, their own pedagogical project. Only under this condition teachers can be "interesting to themselves", they will be able to arouse positive emotions in their students, will be able to educate in children an experience to be themselves, teach them to overcome the difficulties of understanding the reality.

What is pedagogical methodology able to help in resolving numerous issues related to teaching activity? We believe that the first thing many researchers should do, it is to rise to the level of general philosophical methodology. S. Honcharenko fairly pointed in this regard the following "paradoxical and alarming situation happened to the theory of pedagogical science in Ukraine. On the one hand, formal data (that is hundreds of presented theses on pedagogical sciences, hundreds of published monographs and dozens of new textbooks on pedagogy; emergence of new scientific and educational departments of pedagogical sphere in higher educational institutions) demonstrate the ongoing development of pedagogical knowledge. With general increasing of the average level of education, with increasing number of studies culture of scientific thinking, methodological and theoretical level of research evidently decline". Further scholar stated that "... too often serious pedagogical problems (philosophy of education, its continuity, democratization, fundamentalization, humanization, standardization, informatization, "textbook creation", etc.) are considered at pragmatic, and sometimes even at the mundane level [6, c. 37].

So, as it can be seen from the former context S. Honcharenko not rejecting the principles and methods of general scientific and specific scientific levels, is obviously in favor of increasing the role of general philosophical methodology in pedagogical researches. In our view, this approach is valuable in the context of comprehending the problems of pedagogical activity. What are its benefits?

In modern conditions pedagogical methodology is a reliable guide that identifies regularities and formation of all the systems of practical pedagogical activity. Based on quantitative and qualitative changes it allows to prove the most effective mechanisms of the regulation and functioning of pedagogical action, to define spiritual and cultural context of pedagogical activity, and to analyze value-semantic component of pedagogical activity. Based on the general dialectical principle on the interrelation between things and social phenomena pedagogical methodology allows to reveal deep 
interaction between pedagogical thinking and activity, to explore the conditions under which pedagogical activity becomes moral and aesthetic phenomenon, and so on.

Teachers-practitioners having certain amount of knowledge on methodology are capable to reflect on their pedagogical activity and to identify the causes of success and failure of students, to explore the difficulties that arise in the process of learning materials of a new type, etc. Academician V. Krayevskyi distinguished main methodological issues that the future teachers need to learn. They are as follows: 1) methodological literacy as a prerequisite for an effective scientific and practical pedagogical activity; 2) unity and division between pedagogy as a science and teaching practice; 3) teacher in the system of communications between pedagogy as a science and teaching practice; 4) research methods in teacher's practice; 5) scientific and pedagogical knowledge necessary for teachers to understand their own activity as a condition of its effectiveness; 6) system of pedagogical problems as the content of a teacher's activity; 7) problem as a part of methodological reflection; 8) mental experiment as a way to find solutions to the problem of pedagogical goal; 9) methodical reflection as part of methodological culture of a teacher; 10) long-term objectives as one of the stages of teachers' projecting their own systems of work [10, c. 129]. Unfortunately, teachers often boast of such question posing and believe that they, as practitioners, do not need it. They do not realize the fact that pedagogical activity quickly degenerates into craftsmanship without scientific understanding. But today it is extremely unacceptable for teacher to become craftsman. Pedagogue is aimed to be a creative and competent individuality on both empirical and theoretical levels. Undoubtedly, all this is closely related to the fact of quality and content of such pedagogical education that future teachers receive.

\section{Methodology and content of pedagogical education}

Any education is a complex social phenomenon, the process and the result of mastering by individuality certain system of sciences, knowledge, practical skills, abilities and associated with it development of its intellectuallycognitive, artistic activity as well as moral and aesthetic culture. The main aim of pedagogical education is preparing specialists to the work in the educational sphere. The specificity of pedagogical education is determined by increased social demands for professional activity and individuality of a teacher as a subject of educational communication and pedagogical process. Therefore, pedagogical education is aimed to solve two sets of interrelated problems: first of all, to promote socially valuable personal development of future teachers (their fundamental, common cultural, moral and social maturity) and secondly, to help them in professional development and specialization in pedagogical activity [7, c. 646].

The content of pedagogical education is primarily determined by the needs of society and individual that finds its real reflection in the educational qualifying standards, concepts, programs and more. The scope and character 
of the content of pedagogical education is also determined by the type and level of the educational institution, content of subjects and age features of students. We should note that for the past quarter of a century we observe "waterfall" of diverse concepts, paradigms, approaches to determining the content of teacher education, however still have lack of well-designed standards (except the obsolete ones). Some of them contradict each other, and all of this, in our opinion, logically results from the "reformist fever" that almost every year is imposed on us by incompetent officials in terms of education. S. Honcharenko fairly pointed that poor understanding of educational matter by many officials, leads to significant losses not only in theory but also in practice of making the content of pedagogical education. Hereto is added the fact that the inability to determine properly the content of national pedagogical education provokes uncritical transfer of someone else's experiences on native soil that is not just unproductive but is largely a disastrous matter.

Instead, we believe that thorough knowledge and intelligent use of pedagogical methodology can help in solving this extremely important issue. What it can exactly help?

First of all, it can help to fill the standards of pedagogical education with the general cultural and national elements.

Secondly, it can help to outline clearly the content of pedagogical education with the idea of pedagogization of both educational and public space.

Thirdly, taking into consideration low level of ecological culture of citizens and connected with it huge environmental problems it would be appropriate to include the issue of ecological culture of a personality into the content of each pedagogy subject.

Fourthly, the content of pedagogical education should reflect more specifically and consistently the issue of personality socialization. The basis of this statement should take developmental-optimistic principle of education and upbringing as it was proved on highly methodological level in the monograph by O. Budnyk [1].

Thus, all the phenomena that require study of the problem of the educational process improvement, teachers training, fully developed personality of a pupil/student, etc. demand high methodological culture from teacher-researcher.

\section{Methodological culture of a teacher}

General conceptual approaches concerning determination of the nature and content of methodological culture of a teacher and the ways of its improvement are already studied by many scientists (S. Honcharenko, V. Zahvyazinskyi, I. Zyazyun T. Levovytskyi, P. Kabanov, V. Krayevskyi, A. Hodusov and others). Scientists are unanimous in the opinion that the study of highly complex problems of modern pedagogy is impossible without a subject that has a high level of methodological culture. They outline different definitions of the notion of "methodological culture". We stick to the 
concept suggested by V. Krayevskyi in his study: "speaking about methodological culture of a teacher, we mean primarily the culture of thinking specific to the sphere of education. It foresees knowledge of methodological standards and ability to apply these standards dealing with educational problems. Its main components are the ability to design and construct the educational process; the ability to understand, formulate and solve problems creatively; the ability to carry out methodical reflection" $[10$, c. 123]. What is very important in the study by V. Krayevskyi, is that he does not only present a model of this phenomenon, but also outlines the common and different features in content of methodological culture of a teacher practitioner and teacher-researcher [10, c. 124-127].

Basing on the theoretical analysis of scientific facts O. Hodusov emphasizes the most significant trends in the formation of methodological culture of a teacher. They are:

a) dependence of teacher's methodological culture formation on epy requirements of a society and needs of educational institutions;

b) dependence of methodological culture of a teacher on social-cultural and educational environment;

c) dependence of the effectiveness of teacher's methodological culture formation on the high level of reflexive control of this process;

d) dependence of the effectiveness of teacher's methodological culture formation on the system of additional pedagogical education.

The scientist considers following principles of methodological culture formation of a teacher:

a) the principle of ethical and anthropological orientation of the process of methodological culture formation of a teacher, which involves the development of a teacher as an integral person, reorientation of teacher's consciousness towards activation of his career, mastering the ideals and values that teacher should implement in his own form of professional life;

b) the principle of innovative and methodological orientation of a teacher to his professional activity, that reflects the integrated nature of the process of methodological culture formation, specific forms of the process of formation, and indicates the ways and means of releasing all the creative forces of a teacher;

c) the principle of methodological reflection of professional being of a teacher, which encourages him to form the necessity of constant self-improvement as an individuality;

d) the principle of self-determination of the individuality of a teacher in a culture that assumes that the dynamics of methodological culture formation is provided primarily by the personal development [14].

The content of the above stated shows that the acquirement of methodological culture of a teacher is not an end in itself, it should help to ensure that obtained research results were popular both among researchers and teachers-practitioners in their professional activity.

On the basis of the performed analysis we can conclude the following: 
1. The methodology examines the process and the results of research. Pedagogic methodology examines the process and the results of pedagogical research; it helps to establish unity between pedagogical science and practice.

2. The main objective of pedagogical methodology as a science is the study of pedagogical reality and pedagogical activity.

3 . Results of the research, their validity and relevance in practice are directly dependent on the level of methodological culture of a teacherresearcher.

The further research can be based on the issues concerning methodological reflection in scientific work; argumentation techniques in formation theoretical model; axiological aspects of research and monitoring of theoretical models, etc.

\section{References}

1. Budnyk O. Profesiyna pidhotovka maybutnikh uchyteliv pochatkovoyi shkoly do sotsialno-pedahohichnoyi diyalnosti : teoriya I metodyka: monohrafiya (Professional training of primary school teachers to social and pedagogical activity : theory and methods). Dnipropetrovsk, 2014.

2. Vashchenko H. Vykhovnyi ideal (Educational ideal). "Poltavskyy visnyk", Poltava, 1991.

3. Gegel G. Filosofiya prava (Philosophy of law). Mysl, Moscow, 1990.

4. Honcharenko S. Metodolohiya (Methodology). Entsyklopediya osvity. 2008. P. 488-500.

5. Honcharenko S. Pedahohichna nauka (Pedagogical science). Entsyklopediya osvity. 2008. P. 644-646.

6. Honcharenko S. Metodolohichni zasady pobudovy pedahohichnoyi teoriyi (Methodological framework of educational theory formation). Profesiyna osvita : pedahohika i psykholohiya. 2012. P. 37-48.

7. Yevtukh M. Pedahohichna osvita (Pedagogical education). Entsyklopediya osvity. Kyiv. 2008. P. 646-647

8. Yershova L. Transformatsiya vykhovnoho idealu v Ukrayini (XIX pochatok XX stolittya). Kyyivskyi, Odeskyi, Kharkivskyi navchalni okruhy : Monohrafiya (The transformation of the educational ideal in Ukraine (XIX - XX centuries. Kyiv, Odessa, Kharkiv educational districts). Zhytomyr, 2015.

9. Zyazyun I. Pedahohichna psykholohiya chy psykholohichna pedahohika? (Pedagogical psychology or psychological pedagogy?) Estetyka i etyka pedahohichnoyi diyi. Zbirnyk naukovykh prats. № 3. 2012. P. 20-37.

10. Krayevskiy V. Metodologiya pedagogiki: novyi etap: uchebnoye posobiye dlya stud. vyssh. ucheb. zavedeniy (The methodology of pedagogy: a new stage: textbook for students). Izdatelskiy tsentr "Akademiya", Moscow, 2006. 
11. Zyazyun I., Kramushchenko L., Kryvonos I. ta inshi. Pedahohichna maysternist : Pidruchnyk (Art of teaching: Textbook). Vyshcha shkola, Kyiv, 1997.

12. Rubinshteyn S. Printsipy tvorcheskoy samodeyatelnosti (K filosofskim osnovam sovremennoy pedagogiki (Principles of creative initiative (To the philosophical foundations of modern pedagogy). Voprosy psikhologii. № 4. 1986. P. 101-109.

13. Stechenko D., Chmyr O. Metodolohiya naukovykh doslidzhen: Pidruchnyk (Methodology of scientific research: Textbook). Znannya, Kyiv, 2007.

14. Khodusov A. Metodologicheskaya kultura kak usloviye sovershenstvovaniya i obogashcheniya professionalnoy podgotovki uchitelya (Methodological culture as a condition of improvement and enrichment of the professional training of a teacher). Electronic resource. Mode of access: http:// www.geocities.com/gazetka/xix uman.html

15. Okoń Wincent. Nowy slownik pedagogiczny. Wydanie czwarte uzupelnione i poprawione. - Warszawa: Wydawnictwo Akademicke «Zak» 2004. - S. 246. 